\title{
Ondanks de regels zoeken naar een waardig afscheid
}

\author{
Als iemand met (een verdenking op) \\ covid-19 overlijdt, is passend afscheid nemen bijna onmogelijk. 'Het \\ blijt moeilijk dat er zoveel beperkingen zijn aan sociaal contact, zeker \\ in de stervensfase.'
}

tekst Jeroen Wapenaar fotografie ANP / Marcel van Hoorn

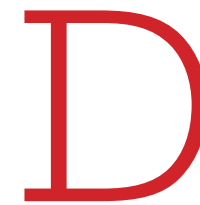
e overtuiging dat ieder mens waardig moet kunnen sterven, is diepgeworteld in onze samenleving. De behoeften van de patiënt én de naasten horen daarbij leidend te zijn, benadrukt het Kwaliteitskader palliatieve zorg Nederland. ${ }^{1}$ Maar bij covid-19 is passend afscheid nemen vaak niet mogelijk, en dat zorgt voor veel verdriet, bij nabestaanden en ook bij verpleegkundigen.

\section{Machteloos}

Het gevoel van machteloosheid is er nog steeds, zegt verpleegkundige en palliatief consulent Marij Schielke als ze vertelt over de cliënt die enkele weken geleden overleed aan vermoedelijk covid-19.

Deze 72-jarige meneer woonde nog thuis, had een longcarcinoom met botmetastasen en leefde al een tijd met pijn die met oxycodon redelijk onder controle was. De verwachting was niet dat hij op heel korte termijn zou overlijden, zegt Schielke. 'Toen begon hij ineens veel te hoesten, kreeg ernstige dyspneu en werd onrustig. Zijn lichamelijke conditie ging in sneltreinvaart achteruit. Mogelijke oorzaken van onrust als retentieblaas, obstipatie en delier waren uitgesloten. Deze meneer had besproken

\section{PALLIATIEVE ZORG BIJ COVID-19}

p Palliaweb staan de meest relevante richtlijnen en handvatten over palliatieve zorg bij covid-19 gebundeld, kijk op palliaweb.nl/corona. De informatie wordt dagelijks aangevuld, ook met documenten van zorginstellingen. Je vindt er bijvoorbeeld adviezen/aanbevelingen over symptoombestrijding, verzorging na overlijden en de communicatie. Vlaamse verpleegkundigen kunnen terecht op palliatief.be, de website van de Federatie Palliatieve Zorg Vlaanderen, die onder andere extra nieuwsbrieven deelt over palliatieve zorg bij covid-19 (publicaties > tijdschrift \& nieuwsflash). 


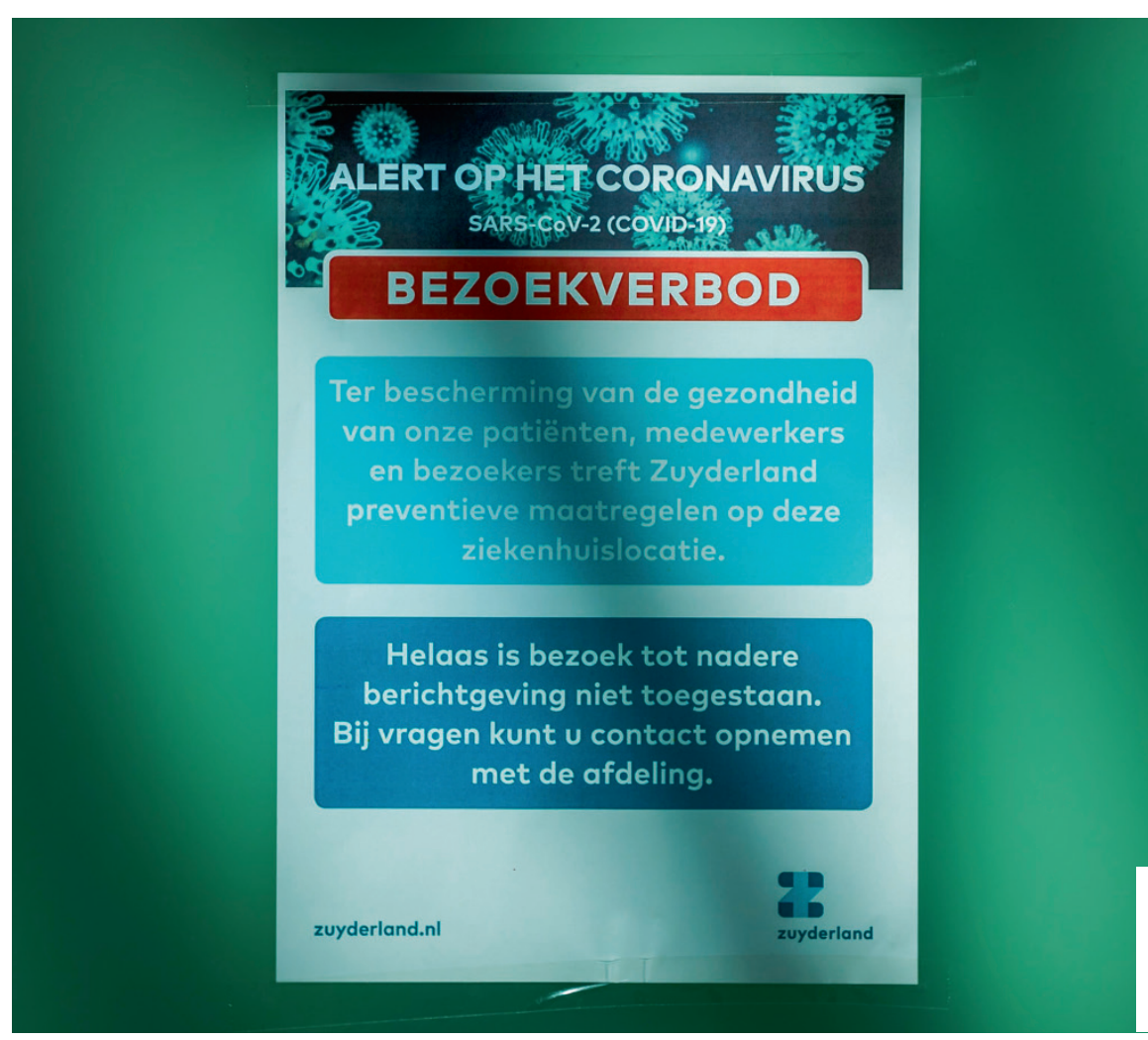

meneers laatste wens, dat al zijn familieleden en vrienden na zijn overlijden zouden toosten op het leven, is het natuurlijk ook niet gekomen. En omdat niet $100 \%$ zeker is of hij covid-19 had, blijven ze ook met die vraag worstelen.'

Ook voor Schielke zelf, 45 jaar werkzaam in de zorg, waarvan 20 jaar als palliatief verpleegkundige, is de casus heel ingrijpend. 'Ik heb me meerdere malen afgevraagd of ik toch niet meer had kunnen doen, ook al weet ik dat dit virus al zoveel anderen ook zo heeft doen sterven. Zelden heb ik iemand zo snel achteruit zien gaan. En ook al reageerden alle naasten heel begripvol, het blijft moeilijk dat er zoveel beperkingen zijn aan sociaal contact, zeker in de stervensfase.'

\section{Palliatieve corona unit}

Verpleegkundigen in het ziekenhuis hebben het ook moeilijk met hoe snel mensen bij covid-19 overlijden en hoeveel beperkingen er zijn aan bezoek, zegt verpleegkundig consulent palliatieve zorg Steintje Brands. 'Ook is een uitgebreid gesprek voeren over de behoeften van een patiënt lastiger, mede door de benauwdheid, en omdat zelfs iemand die nog redelijk fit oogt en goed communiceert binnen enkele dagen tot uren kan overlijden.'

Om het afscheid waardiger te maken heeft haar werkgever, het OLVG in Amsterdam, op beide locaties een Palliatieve Corona Unit opgezet. In totaal zijn er 8 bedden voor patiënten die waarschijnlijk binnen een week komen te overlijden. Per dag mogen 2 bezoekers langskomen, zij moeten wel beschermende kleding dragen, tenzij ze huisgenoot zijn van de patiënt. Raakt een bezoeker de patiënt aan, dan moet hij 2 weken in thuisisolatie verblijven.

\section{'Zelden heb ik iemand zo snel achteruit zien gaan'}

$\Delta$ Dat de patiënten niet kunnen overlijden in het bijzijn van hun naasten, maakt het voor alle partijen extra zwaar. (Foto ter illustratie)

\section{COMIMUNICEREN OVER BENAUWDHEID}

' $M$

rijk om dat uit te leggen aan de familie. Schep geen onrealistische verwachtingen, maar houd er rekening mee dat niet iedereen het aankan om de moeilijke waarheid onder ogen te zien. Stel open vragen en bied ruimte om te praten over wat komen gaat', zijn adviezen uit het zakkaartje Palliatieve zorg in coronatijd, gemaakt door het Jeroen Bosch Ziekenhuis in Den Bosch en $\mathrm{O}^{2} \mathrm{PZ}$ (Programma Onderwijs en Opleiden Palliatieve zorg). 'Mensen zijn vaak extreem moe en extra kwetsbaar door onderliggend lijden en kunnen in heel korte tijd snel achteruitgaan. Je klinische blik kan je in de steek laten. Het is belangrijk om daar als zorgverlener rekening mee te houden. Wacht er niet mee om aan de bel te trekken als je twijfelt. Raadpleeg het team palliatieve zorg in jouw regio bij complexe zorg.' 
CLL van loghum

Stafleu

van loghum

Cohn

stafleu

van loghum

bohn

stafleu

van loghum

f bohn

$\$$ stafleu

van loghum

CCS bohn

3 stafleu

van loghum
CCS bohn

8S stafleu

van loghum

CC bohn

stafleu

van loghum

SCS bohn

\& stafleu

van loghum

SCS bohn

3 stafleu

van loghum

SCS bohn

stafleu

van loghum

CS bohn

CL van loghum

CSS bohn

SC bohn

8 stafleu

van loghum

SCS bohn

cCohn stafleu

van loghum

cef bohn

30 stafleu

L van loghum

cCe bohn

$8)$ stafleu

LL van loghum

cec bohn

$3)$ stafleu

- van loghum

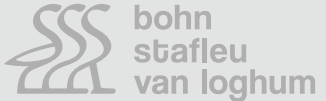

cCe bohn

S) stafleu

van loghum

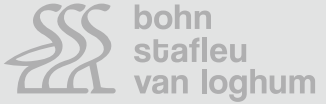

cCohn

D) stafleu

van loghum

$\int S \begin{aligned} & \text { bohn } \\ & \text { stafleu }\end{aligned}$

C. van loghum

cC bohn

9) stafleu

van loghum

SS bohn

. van loghum

bohn

stafleu

van loghum
cCe bohn

8 stuafleu

van loghum

\section{CSS bohn stafleu \\ C. van loghum}

8SS bohn

stafleu

stafleu

van loghum

stafleu

van loghum

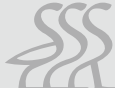

SS

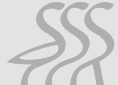

SCS bohn

PStafleu

(1) van loghum $\iint \begin{aligned} & \text { bohn } \\ & \text { stafleu } \\ & \text { van loghum }\end{aligned}$

Cec bohn

8 stafleu

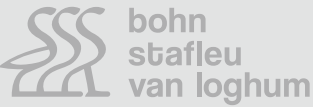

SCS bohn

van loghum

cec bohn

Stafleu

C van loghum

SSS bohn

van loghum

CCS bohn

8 stafleu

CL van loghum

SSS bohn

van loghum

CSS bohn

8) stafleu

CL van loghum

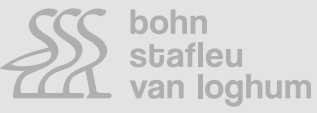

SCS bohn

8) stafleu

CL van loghum
SCS bohn

stafleu van loghum

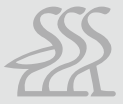

SCS bohn

$8 \int$ stafleu van loghum

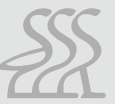

SSS $\begin{aligned} & \text { bohn } \\ & \text { stafleu } \\ & \text { van loghu }\end{aligned}$ van loghum

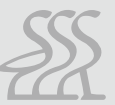

SSS bohn van loghum 


\section{VERZORGING NA OVERLIJDEN BIJ (VERDENIKING OP) COVID-19}

- De overledene krijgt een chirurgisch mondneusmasker op omdat tijdens het draaien nog lucht uit de longen kan komen.

- Naasten mogen deelnemen aan de verzorging, maar moeten wel een schort met lange mouwen en handschoenen dragen, eerst het schort aantrekken en dan de handschoenen (over de manchetten van de mouwen).

- Een veiligheidsbril en mondneusmasker zijn niet nodig, met 1 uitzondering: naasten met ziekteverschijn- selen passend bij covid-19 of een andere virale infectie moeten wél een (chirurgisch) mondneusmasker dragen en deze ophouden tot ze buiten de instelling zijn. Dit geldt ook voor naasten die niet deelnemen aan de verzorging maar wel aanwezig zijn.

- Ook met handschoenen aan mag het eigen gezicht niet worden aangeraakt.

- Bij het uittrekken van de beschermende middelen is de volgorde andersom: eerst de handschoenen uitdoen, daarna handhygiëne toepassen, dan het schort uittrekken en vervolgens weer handhygiëne toepassen.

- De naaste mag de overledene niet kussen, handcontact mag wel met handschoenen aan, daarna moeten de handen goed worden gewassen.

- Zie voor meer aanbevelingen het document 'Informatie over zorg na overlijden, voor naasten, zorgverleners en uitvaartmedewerkers', opgesteld door artsen en verpleegkundig specialisten, op palliaweb.nl.
'Hopelijk maakt de sfeer op de unit de stervensfase iets draaglijker', zegt Brands. 'De kamers hebben lichte kleuren en een warme verlichting, we horen dat ze mooi gevonden worden.'

\section{SYMPTOOM- BESTRIJDING IN PALLIATIEVE FASE}

Op Palliaweb staan medicatieadviezen bij dyspneu, pijn, hoesten, delier, misselijkheid en braken, angst, slecht slapen en palliatieve sedatie. Over het algemeen wijken de adviezen niet af van die bij niet-covid-patiënten, zegt verpleegkundige palliatieve thuiszorg Marij Schielke. Wél specifiek voor covid-19, omdat onrust relatief vaak voor lijkt te komen, is levomepromazine (12,5-25 mg subcutaan). Dit is te overwegen bij een mogelijk delier in de terminale fase, omdat dit middel onrust kan verminderen. Bij dyspneu kan bij covid-19 de dagdosering morfine (gestart wordt bijvoorbeeld met 2 dd oraal $10 \mathrm{mg}$ morfine slow release, of 6 dd Oramorphdrank of Oramorph druppelvloeistof, 2,5-5 mg per keer) met $25-50 \%$ worden opgehoogd. De aanbevelingen over symptoombestrijding staan op Palliaweb in het document 'Symptoombestrijding in de thuissituatie bij patiënten met een covid-19 (Corona) in de laatste levensfase', van de Nederlandse Vereniging voor Medische Oncologie (NVMO) en het Nederlands Huisartsen Genootschap (NHG).

\section{Adviezen}

Hoe kunnen verpleegkundigen bij covid-19 bijdragen aan kwaliteit van leven in de stervensfase? Wees nog zorgvuldiger in welke onderwerpen je bespreekbaar maakt, adviseert Brands. 'Ik vraag altijd naar geloof, en naar existentiële onderwerpen. Mensen die jarenlang gevochten hebben tegen een ziekte kunnen het gevoel krijgen dat app PalliArts. Vlaamse verpleegkundigen kunnen terecht bij netwerken palliatieve zorg en palliatieve thuiszorgequipes. Op palliatief.be staat een overzicht (klik op netwerken).

Schielke benadrukt hoe belangrijk het is de impact van covid-19 ook met je collega's te bespreken. 'Als team moet je eveneens door een verwerkingsproces heen, anders kun je die kwaliteit van

\section{'Ook als team moet je door een verwerkingsproces heen'}

die strijd voor niks was. Geef ze de kans hun frustratie en onbegrip uit te spreken.' Twijfel je of je zelf die ruimte kan geven, vraag dit dan aan een geestelijk verzorger, zegt Brands. Bij vragen of twijfels kan ook een consultatief palliatief team advies geven, zegt Schielke. Hoe je een consultatieteam in jouw regio kunt raadplegen staat op iknl.nl, zoek op consultatieteam, of kijk in de zorg ook niet bieden, en verwerken lukt alleen door ervaringen te delen.'

\section{Noot}

1 Het Kwaliteitskader Palliatieve Zorg Nederland is een initiatief van Palliactief, de Nederlandse vereniging voor professionele palliatieve zorg, en kennis- en kwaliteitsinstituut Integraal Kankercentrum Nederland (IKNL). Het kwaliteitskader staat op www.pallialine.n

\section{CONGRES PALLIATIEVE ZORG}

Hopelijk kunnen we in september weer samenkomen, om stil te staan bij de afgelopen tijd en vooruit te kijken in de wereld van de palliatieve zorg. Tijdens het Palliatieve Zorg Congres op 15 september in Ede kun je luisteren naar verschillende experts op het gebied van palliatieve zorg, zoals Sander de Hosson, Margot Verkuylen en Eric Geijteman, en ervaringsdeskundige Frits Spits. Meer informatie op www.palliatievezorgcongres.nl 